\title{
The Words of Mercury, the Songs of Apollo: Collaboration and the Making of Shakespeare
}

\author{
John Jowett (University of Birmingham)
}

Today we inhabit a postmodern era that is no longer so interested in organic unity. In our dispersed and variegated notion of the subject area of English literature, its primary instance, Shakespeare, lies finds itself lying subject to energetic disintegration from many directions. We now face a divide between two ways of looking at Shakespeare: an older, romantic, and perhaps recessive view of the artistic genius as a figure transcendent of his time and place, and a newer awareness of the writer enmeshed in theatre practice and writing to make money. The recent and ongoing scholarship on Shakespeare as a collaborator has inflicted an empirical and probably irreversible defeat on the widespread tendency in the twentieth century to deny any view of Shakespeare as collaborator, and to diminish the extent of his collaborative work. We are no longer shocked to hear the words 'Shakespeare' and 'collaboration' in the same sentence. We are now used to seeing the Shakespeare corpus as being subject to authorial disintegration. Perhaps as many as ten extant collaborative plays, are now thought to be collaboratively written, as also was one lost play that survives as an eighteenth-century adaptation. In at least one and probably two other plays, Shakespeare wrote additional passages for a revision. There are also two plays that survive only in versions that result from adaptation by another dramatist. Over one-third of Shakespeare's dramatic works are not wholly Shakespeare. 
The case for Shakespeare as a collaborator is grounded ultimately not in an ideological position that is opposed to the very concept of the author, but in the increasingly sophisticated work on attribution study that is now enabling us to draw an ever more accurate picture of what Shakespeare wrote, and with whom he wrote it. It is in principle disinterested, and it affirms equally as it denies. The scholarship that informs us that Pericles was written in collaboration with George Wilkins also informs us that neither Wilkins nor any dramatist other than Shakespeare had anything to do with the writing of Twelfth Night. To this extent it is neutral. It proceeds out of curiosity rather than a predetermined view. My own case today is not an exercise in attribution study, and it is not so neutral. It explores one of the ways in which the information yielded by attribution study can be used to generate a new understanding of Shakespeare's art.

I will not pursue this line of enquiry exhaustively. I have written elsewhere about how Shakespeare was a good collaborator, in the sense that the contributions made by him and his collaborator can be seen to complement, complicate, contradict, and finally enrich each other in productive tension. My case in point was Timon of Athens, written in collaboration with Thomas Middleton. I can imagine a paper describing Shakespeare as a bad collaborator, whose writing can seem to have a lofty and uncongenial indifference to that of his colleagues, and there will be some suggestions in this direction in my present paper. But my narrative rather than judgemental. I aim to argue that Shakespeare immersed himself in the practice of collaboration at the beginning of his career to an extreme degree, using this practice as a way of developing his skills in writing plays; but that, having achieved this goal, he strongly and decisively renounced this practice in order to establish himself as an in-house dramatist: a share-holder, therefore, in the theatre company, but a non-sharer in the act of writing.

This abrupt transition can be associated with two plays, Richard III and Love's Labour's Lost, of which more later, and a poem, Venus and Adonis, with which I begin. When Venus and Adonis was printed in 1593, no-one would have recognised its author William Shakespeare as a literary poet. It was his first published exercise in non-dramatic verse, and the first work to identify him as author. It declares its authorship and claim to a place claim in the world of letters not on the title page but on the following leaf (sig. A2), which presents an epistle 'TO THE RIGHT HONORABLE Henrie Wriothesley, Earle of Southampton, and Baron of Titchfield'; the epistle is signed 'William Shakespeare'. In dedicating his poem to Southampton, the unknown Shakespeare could scarcely have aimed higher, for Southampton was beginning to replace Sir Philip Sidney (who had died in 1586) as the inspirer of poetry and military heroism. The claim to high poetic achieve- 
ment is articulated in the Latin motto on the title-page, printed in the space immediately below the title itself, in the very space where the author's name would usually appear (see illustration):

Vilia miretur vulgus: mihi flauus Apollo

Pocula Castalia plena ministret aqua.

The editors of the Arden edition of the Poems, Katherine Duncan-Jones and Henry Woudhuysen, translate these lines from Ovid as follows: 'Let common people gawp at common things: may golden-haired Apollo serve me with his goblets served from the Castalian waters'. The lines present poetry as inspirational. It comes from a divine source, Apollo god of poetry; it consists of Castalian waters held in golden vessels; it is pure, having flowed directly from that divine spring. This is a view of poetry as set apart from common objects, as admired by common people. Indeed, at first sight at least, it is set off from everyone, as the god is made serving-man to the one poet: 'may golden-haired Apollo serve me'. These are not the lines of a collaborating co-author.

The distinction that Shakespeare co-opts for himself is between the art of the so-called 'common people' and high art; or between the explicitly mentioned Apollo and the implicitly referenced Mercury, the god of trade and of theft, the source of the English words merchant, mercantile, mercenary. And the diary of Philip Henslowe recording the financial transactions of a theatre company in the late 1590s strongly verifies the connection between a commercially driven model of artistic production and the collaborative writing of plays. The majority of plays listed in his Diary were written in collaboration. Shakespeare wrote for a different company, but one that was commercial nonetheless. In the late play The Winter's Tale the pedlar and ballad-seller Autolycus, as he tells us himself, was 'littered under Mercury' (4.23.25): a sign that Shakespeare ultimately embraced rather than renounced the notion of art as popular, commercial, perhaps even dishonest.

Mercury is also the messenger god, and when a messenger disrupts the festivities at the end of in Love's Labour's Lost he is a messenger whose name, carefully mentioned in the dialogue, refers to the god; he is called 'Mercade'. This would be a casual detail, if it were not for the play's enigmatic closing lines that bring Mercury-and Apollo- to the fore. After Holofernes's motley group of entertainers Nathaniel, Costard, Mote, Dull, and Jaquenetta have sung the songs of Spring and Winter, we read at the very end of the play the cryptic line, 'The wordes of Mercurie, are harsh after the songs of Apollo.' This motto presents the same 
John Jowett

division between two notions of art, the commercial and the divine, represented by the two deities, as the epigram to Venus and Adonis. In the dramatic context the words are puzzling: do they mean that the words of Mercade are harsh after songs

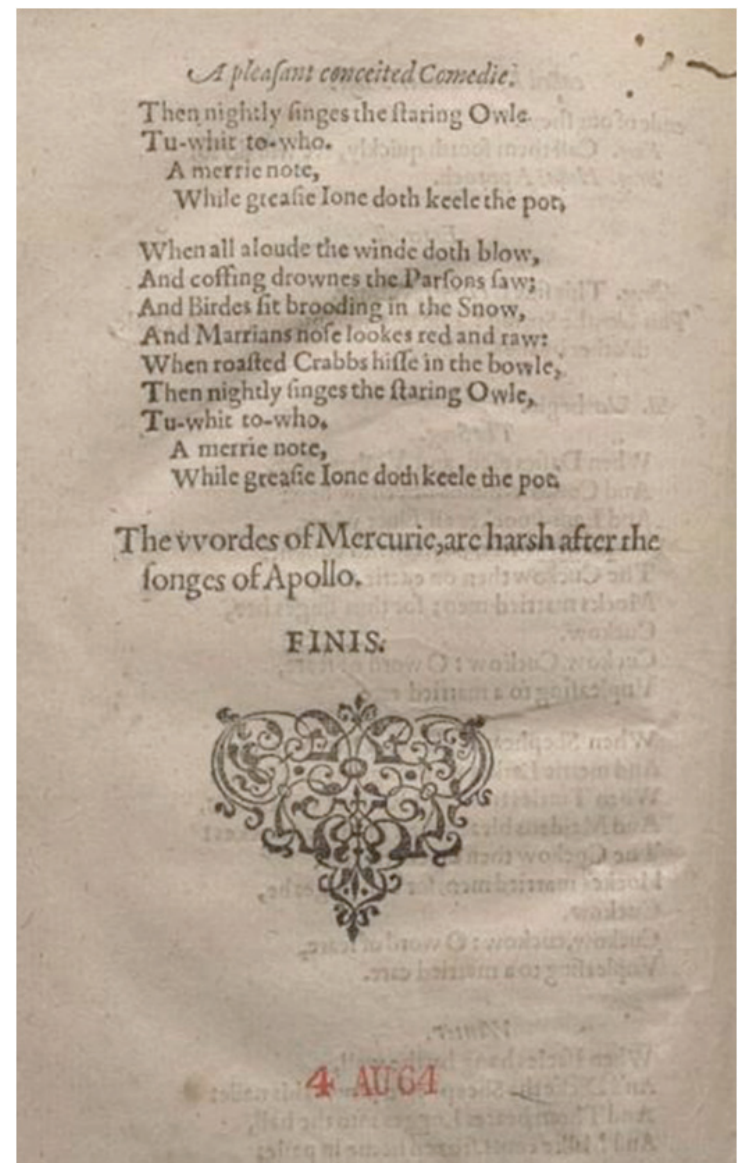

William Shakespeare, Love's Labour's Lost, First Quarto, 1598

that have actually been performed after them, and are themselves a kind of popular entertainment? Can we really make the leap, as the New Penguin Shakespeare editor George Hibbard suggests, of relating "the songs of Apollo" to the sonnets the courtiers recited way back in 4.3? Given the enigmatic quality of the words in the dramatic context, we might explore the idea that the words are some kind of lapidary comment on the play as a whole. The presentation they are given in the First Quarto of 1598 offers surprising and emphatic support to this view. The words are set in an unusually large font, giving the impression that they are not words from the play but words about the play (see illustration). The absence of a 
speech-prefix and exit may also be deliberate in setting the play's gnomic final words apart from the dialogue. In the Folio text the play the line is attributed to ' $B r a g$ ', that is to say the braggart Armado, whose speech now concludes with a cue for an exeunt, 'You that way, we this way'. This line is not to be seen in the 1598 quarto, and it is fair to suggest that they might have been omitted specifically in order to shift the text out of the mode of dramatic dialogue and into the mode of framing paratext. Quite possibly Shakespeare himself arranged for this effect. We do not usually consider him to have taken an interest in the publication of his plays in print, but in this case we are looking at the year when Shakespeare's name first appeared on the title page of plays, with Love's Labour's Lost a member of the first group in which this happened. Indeed it may have led the way, especially as there is evidence that an earlier and now lost quarto was published in 1597. In other words, we can align Venus and Adonis with Love's Labour's Lost as Shakespeare's two texts that use the textual resource of paratext to present the high Apollonian claim. The first printed work by Shakespeare (I except Arden of Faversham, to which Shakespeare probably made a contribution), and the first play to declare him as author: these happen to be the two printed books with special inscriptions separating his own lofty verse from the Mercurial or mercantile writing of others. And we can relate these two editions to much larger events in the development in Shakespeare's authorial persona.

The publication of Love's Labour's Lost marks the beginning of the phase lasting for the rest of Shakespeare's life, and onwards far beyond until today, in which it is usual to identify him as the author of his dramatic works. This is the era of visible single authorship. The only work published in an early edition identifying Shakespeare as a collaborator was Two Noble Kinsmen, a late play written in collaboration with John Fletcher, published in 1634, years after Shakespeare's death and the publication of the 1623 First Folio. The only modern edition to draw attention to Shakespeare's collaborators fully, clearly and openly is the Oxford Shakespeare of 1986. Clearly, the Folio moulded our image of Shakespeare as a sole author. This volume omitted collaborations such as Two Noble Kinsmen and Pericles; it included some collaborative plays without mentioning any coauthors, and it strongly promoted an image of Shakespeare as a writer who is single, separate, and uninfluenced by others. The famous frontispiece portrait is the most conspicuous element in a sustained drive in this direction. In assessing this picture of Shakespeare on his own terms as an Apollonian writer, we should remember that the Folio itself was littered under Mercury: a book whose presentation is anxiously crafted to ensure, above all, that it will sell. 
With this framework of book history in mind I return to Shakespeare's first Apollonian moment, his publication of Venus and Adonis in 1593. In choosing his motto from Ovid, Shakespeare is, I believe, responding to Greene's Groatsworth of Wit (1592), in which the dying Robert Greene, in a famous letter addressed to 'those Gentlemen his Quondam acquaintances, that spend their wits in making plaies', gives the gentleman-playmakers a sharp warning:

Yes, trust them not. For there is an upstart crow, beautified with our feathers, that with his "Tigers heart wrapped in a player's hide" supposes he is as well able to bombast out a blank verse as the best of you; and, being an absolute Johannes Factotum, is in his own conceit the only Shake-scene in a country.

The 'Shake-scene' is clearly Shakespeare by virtue of both the allusive play on his name and the paraphrase of 'his' line in 3 Henry VI, "O tiger's heart wrapped in a woman's hide" (1.4.137). Shakespeare is accused of being a Johannes Factotum, or Jack of all trades. The exact meaning of these accusations has been debated, but it seems likeliest that he implies that Shakespeare is attacked as an actor who has jumped tracks to become involved in writing plays.

The pamphlet was written at a key moment in English theatrical history. The plague had forced the closure of the theatres in 1592. In this period the playing companies went through a transformation; some disappeared; others emerged as regroupings of players from different companies. The most notable of the regrouped companies was the one with which Shakespeare would be associated, the Lord Chamberlain's Men. Of equal or more profound impact around this period was the passing of an old generation of dramatists. Greene was dead already, and Christopher Marlowe was about to be murdered in a pub brawl on 30 May 1593, about six week after Venus and Adonis was entered in the Stationers' Register. The deaths of Marlowe and Greene brought the first major phase of play-scripting for the London commercial theatre to a close. George Peele and Thomas Kyd were spent forces. Neither would contribute further to the development of English drama. Who was left? The poet described in the Groatsworth as the 'young Juvenal' Thomas Nashe had far to go, but mainly in the field of prose pamphlet writing; the only play he is known to have written after 1592 is the lost collaboration with Jonson, The Isle of Dogs (1597). Another established dramatist, Thomas Lodge, wrote no plays after 1589. And then there was Shakespeare-though born the same year as Marlowe and a relative newcomer, yet by 1592 a name so well known 
that the Groatsworth's readers would recognise him in the guise of 'Shake-scene', so clearly associated with well-known plays that its author could pointedly misquote a line from one of these plays and expect his readers to recognise it. And all this before anything of Shakespeare's had recognisably appeared in print. Despite the absence of Shakespeare in print, despite the lowly authorial status of playwrights in general, despite the even lowlier status that the Groatsworth accords to Shakespeare himself, despite the obfuscations of collaborative authorship, the pamphlet tells us that Shakespeare by 1592 had in some sense arrived, and was recognised.

But this was a sullied and compromised kind of arrival. Its classical point of reference was not the water of Ovid's Castalian spring, but the stolen feathers of Aesop's, or perhaps rather Horace's, crow. The pamphlet's 'us' of 'our feathers', 'you' of 'as well able to bombast out a blanke verse as the best of you' set him up in opposition to the established professional dramatists who are allusively identified as Marlowe, Peele, and Nashe. Shakespeare is different from them, not, as he would soon claim himself, because he is supremely excellent and pure, but because he is an intruding outsider. And so the debate between Greeene's Groatsworth of Wit and Venus and Adonis becomes about how to place an outsider: whether, on a vertical axis, he appears above or below the insiders. For 'Greene' he is an intruder, a mere actor, we might infer, of no university education who robs the dramatists of their proper due-whether that due is defined in terms of employment, financial reward, literary property, or fame. Shakespeare is guilty of 'bombast', of encroachment on the territory of the dramatists, and perhaps of plagiarism. If the exact implication of the charge against Shakespeare's writing techniques is left obscure, this may well be deliberate: implication can be a stronger mode of accusation than something more direct and testable. One implied accusation is that Shakespeare has picked up the techniques of dramatic writing from the plays in which he and his company have performed. Not content with imitating, he now claims to outdo the established dramatists.

The playwrights would have had no rights over their scripts once they had sold them on to the players, and one of the epistle-writer's concerns is surely that, if the acting company could generate scripts in-house, the income stream as well as the professional standing of the dramatists would be endangered. Greene's Groatsworth of Wit accuses Shakespeare of abusing professional demarcations between actor and dramatist, and perhaps of undermining the informal protocols by which collaboration could take place. The Groatsworth reminds us that collaborative texts emerge from the work done in lived lives. Sadly, its animal imagery associates Shakespeare with the principle of aggressive, appropriative collaboration: the tiger's heart, the upstart crow. The writer's mentality in making such accusations is counter- 
collaborative: dramatic writing is seen as belonging to its authors, and as being distinctive of them. There are identifiable boundaries, and they are under threat. In transgressing the professional boundary between acting and writing, the actordramatist also transgresses the boundaries of authorship itself.

Nevertheless, the allegation against Shakespeare is exaggerated, in some ways untrue, and even self-cancelling. Every shred of evidence suggests that the most beautiful feathers of the Shakespeare collaborations were those of Shakespeare himself. And the Groatsworth backhandedly recognises this. If plagiarism is one possible implication of the Groatsworth's words, yet it is not quite the right term if the famous line, the line parodied, is, after all, 'his', Shakespeare's. He is 'beautified with our feathers', and yet, by that annoying contradiction, beautified with wellrecognised feathers of his own. The Groatsworth's deployment of the language of theft conflicts with its contrary suggestion that Shakespeare writes in a distinctive and memorable style. A famous line representing a high-point of dramatic emotion is firmly tagged as being recognisably, and indubitably, by Shakespeare. He is therefore at the same time both above and below the established dramatists on the scale of authorial value: the bad hypo-author - a mere literary thief - and the good hyper-author - a famous and strongly differentiated master of his own style.

Such an accusation clearly could be levelled, and to that extent the idea that the author is a product of the eighteenth-century copyright legislation is challenged. The court by which such judgements are made is not, however, a court of law; it is what Alexandra Halasz calls 'the marketplace of print'. Print, to a greater extent than the theatre, demands the author function, and writers such as Greene were precociously insistent on their status as authors. The Groatsworth is itself a symptomatic product of the print industry. Interestingly, it presents a case in point of its own authorial identification being both crucial to the functioning of the text and, by an inescapable irony, false. It was edited and in likelihood part-penned by the book-industry stationer and would-be writer Henry Chettle. The Groatsworth presents a journalistic blend of fictional romance and social satire, in which scandals associated with individual dramatists such as Shakespeare and Marlowe are incorporated into the pamphlet, as a token of their news value. The semi-fictional author given the name Greene is he who can speak of authors. Dramatists are assumed to be known and recognisable figures to the extent that they can be identified allusively as a 'Shake-scene' or a 'Machiavel'.

The image of Shakespeare presented in the Groatsworth did not stick. In KindHeart's Dream, Chettle, apologising for his role in defaming Shakespeare a matter of weeks after the event, wrote: 
I am sorry as if the original fault had been my fault, because my self hath seen his demeanour no less civil than he excellent in the quality he professes; besides, divers of worship have reported his uprightness of dealing, which argues his facetious grace in writing.

In other words, various respectable people have testified that he's a good guy to deal with, which vindicates his effortless skill as a writer. This pamphlet, as much as the Graoatsworth, trades in the journalistic cult of personality. There are hints that Shakespeare has the backing of powerful people. The non-sequitur between personal honesty and felicity as a writer is striking. No matter, because Shakespeare had by this time moved on from collaboration, and so from the accusation of being a plagiarist or thief.

Shakespeare's response in Venus and Adonis itself cannot entirely escape the paradoxes of authorship in general, and print authorship in particular. Contradicting its own claim to disdain the vulgar, Venus and Adonis was issued as a vendible artefact that could be afforded by and was bought by middling readers, and proved to be a hugely popular book, and a big money-spinner for its publishers. In these respects it fits the Mercurial model of commercial art, just as much as the commercial play-script for the theatre. The preliminaries of Venus and Adonis are therefore negotiating obvious ironies. If Shakespeare was to invert the hierarchy that placed him below the professional dramatists, he needed, nevertheless, to accept that his art was to an extent unoriginal. Shakespeare's dedication to the prestigious Earl of Southampton declares his affiliation to be with a patron, and so offsets the model of commercial art: his allegiance is not, we might infer, with a theatre company or a fellow dramatist. In the motto from Ovid's Amores, rather than asserting pure originality, Shakespeare contests the nature of unoriginality. $\mathrm{He}$ says that he participates in the line of inspired poets who ground themselves in poetic traditions going back to the mythical origin and source of inspiration itself. Just as Shakespeare synchronically affiliates himself with the Earl of Southampton, he diachronically affiliates himself with the prestigious Roman poet Ovid, Ovid of 'the elegancy, facility, and golden cadence of poesy' (Love's Labour's Lost 4.2.122). Venus and Adonis is, of course, based on Ovid's Metamorphoses, and so this acknowledgement is apt. Nevertheless, Shakespeare's humility knows its limits. Anyone familiar with Ovid, or William Golding's popular translation of Metamorphoses, would have recognised that Shakespeare's poem was an extraordinarily poetic and embellished elaboration, a knowingly bold and showy assertion of originality and brilliance even more than it is an act of homage to Ovid. 
The extent to which Venus and Adonis marked a new beginning can be seen by looking back from 1593 to the work Shakespeare had written up to that date. We find collaboration everywhere. Even the play that the Groatsworth misquotes, 3 Henry VI, is now suspected of containing more than one hand other than Shakespeare's. It is therefore one possible instance of Shakespeare, in the real or supposed view of the Groatsworth's author, misappropriating the work of others. Recent attribution study tells us more. The cautious and rigorous work of John Burrows and Hugh Craig confirms Gary Taylor's work in arguing that 1 Henry VI is mostly in the hand of dramatists other than Shakespeare, and shows that the second as well as the third parts of the trilogy are also collaborations. 2 Henry VI was written by Shakespeare along with another dramatist, whom Craig identifies as most likely Marlowe, who supplied at least some of the scenes showing Cade's rebellion. ${ }^{1}$ The hands of Marlowe and another dramatist are also to be found in 3 Henry VI. No doubt there is more to be written about the evolution of the Henry $V I$ trilogy in terms of both author attribution and theatre history. But this new picture of Shakespeare collaborating in the Henry VI plays supplies one context in which R.G.'s accusations against Shakespeare can be understood.

There are, however, other plays that R.G. might potentially have had in mind. One of the earliest surviving dramas containing Shakespeare's hand may well be the anonymous Arden of Faversham, written at some point between 1587 and its publication in 1592. Though it has yet to be included in any Shakespeare edition, its part-authorship by Shakespeare has been convincingly demonstrated by Mac D.P Jackson, who identifies Sc. 8, the 'quarrel scene', as Shakespeare's, and by Arthur F. Kinney and others.

It happens that the year in which Greene's Groatsworth of Wit appeared is also the likeliest year for the first performance of a play in which Shakespeare's work is joined with that of another dramatist, Titus Andronicus. George Peele wrote the first act and 2.1. It is Peele whom R.G. most directly warns against Shake-scene: 'I would sweare by sweet S. George, thou art vnworthy better hap, sith thou dependest on so meane a stay.': you don't deserve any better fortune as long as you go on relying on such a miserable support. 'S. George' glances both at Peele's forename and the patriotic tenor of much of his writing. Titus is one play in which the practice of collaboration between Shakespeare and Peele is established, and the potential for real or perceived malpractice therefore exists. And, without speculating further, it does seem a bit 'mean' of Shakespeare (in the modern sense) to take

\footnotetext{
${ }^{1}$ Hugh Craig, 'The Three Parts of Henry VI', in Craig and Kinney, eds, Shakespeare, Computers and the Mystery of Authorship (Cambridge: Cambridge University Press, 2009), 40-77.
} 
over from Peele a soon as Peele had set the play up, and as soon as the action gets really interesting.

Traces can therefore be seen of a pattern that would be consistent with one reading of R.G.'s accusation: that Shakespeare not only imitated other dramatists, but completed scripts that they had initiated. But the other early collaborations might suggest a more fully participating collaborator who was inclined, however, to slow things down, to extend the dramatic and emotional expressivity of the scene, and to steal the show.

So what was the nature of this distinctive talent? The line attributed to Shakespeare in the Groatsworth of Wit's "with his Tygers hart wrapt in a Players hyde" could scarcely be more revealing. Shakespeare is the author of strong female roles. In the source line, "O tiger's heart wrapped in a woman's hide" (3 Henry VI 1.4.138), York's denunciation of Queen Margaret is a moment of high pathos in response to the forceful deeds and sadistic high rhetoric of his female adversary. But the parodied line does not merely identify a role Shakespeare wrote; it configures him as a particular species of author. The Groatsworth's allusion puts Shakespeare himself in a position of analogy with the cruel and foreign woman of his writing. By implication, he is the outsider as Margaret is by both gender and nationality, and he is the sadistically disruptive unnatural presence in the established social, economic, and moral dispensations of play-making. That disruption is substantially grounded on his feminization of the actions of history.

Shakespeare's contribution to Edward III again extends the emotional range of the play and feminizes it. By widespread agreement, he supplied the scenes in which Edward first tries to seduce the Countess and then threatens rape, before stepping back when she threatens suicide, having gained at the last minute "the power to be ashamèd of myself" (3.187). Shakespeare thus broadens the play's concern with chivalry to include the treatment of women as well as warfare, introduces an ambiguity of tone focused on aberrant male sexual behaviour reminiscent of the final scene of Two Gentlemen of Verona or Measure for Measure, and suggests a very deep ambivalence of character in the otherwise bluntly heroic Edward. The section of Arden of Faversham most likely to have involved Shakespeare's authorship is again typical: he writes the so-called quarrel scene between Mosby and Alice, once again reaching to the heart of the moral and emotional complexity of the relationship, here an adulterous one, and once again foregrounding the female role to an unusual degree.

But, as Gary Taylor has recently argued, Shakespeare is also the dramatist who separates out the male protagonist and gives full reign to the expression of his interior emotional world. I agree, though in view of the example of Marlowe's 
heroes I would argue that it would have been harder for the author of Groatsworth to have seen this as Shakespeare's distinguishing feature. Indeed, if one keeps 3 Henry $V I$ as the case in point, it would be easier and more appropriate to argue that Shakespeare is the author who presents a feminized view of men. Tocite roles that are mainly of Shakespeare's authorship, the Duke of York in the famous scene is the victim; the hard woman can reduce the hard man to lamentation and weeping. Soon after Margaret's killing of the Duke of York, Shakespeare presents her husband King Henry withdrawing from the action of the battle action taking place offstage to deliberate on the horrors of war and the impossible responsibilities of kingship; Henry speaks in hypnotically patterned verse lines on the everyday life of the humble shepherd, wistfully recalling the shepherd's nurturing role in the breeding of lambs. This yearning for peace, calm, life, and procreation is brought to an abrupt and ironic halt by the entry of a son who has killed his father in the battle, and a father who has killed his son. Both they and Henry weep when they realise what they have done.

But the narrative of this paper is not about the Shakespearian genius that shines through his collaborative plays. Instead, it is about Shakespeare's provocative and deliberated transition from collaborator to sole artist. What I think this means actually and seriously about Shakespeare is that he collaborated to learn, and that he consistently outdid the dramatists from whom he learnt. If we think of collaboration as a co-ordination of equals, this might clarify the disturbing way in which Shakespeare confuted equality. He is the incomer, the new participant, the apprentice. At the same time he is the competitor, the appropriator, the aspirational better. This is the paradox revealed in the Groatsworth, in Venus and Adonis, and in the pattern of his collaboration as it is revealed by attribution studies.

I will develop the case further the picture of Shakespeare as an atypical collaborator in this early career as dramatist, and an atypical sole author after 1593. Before taking this next step I should enter some caveats. Any view that contrasts the individual exemplified in Shakespeare with the undifferentiated collaborative matrix is misleading if it is taken too far. For one thing, the collaborative matrix is not undifferentiated. As Hugh Craig has pointed out, one thing we are learning from attribution studies is that stylistic affinities between texts are caused by authorship far more than by any other factor such as date, genre, theatre company, and so on. And in collaborative plays it proves not to be the case that individuality is lost in the collaborative enterprise. Moreover, well-known writers such as Kyd, Marlowe, Shakespeare, Jonson, Chapman, and Middleton were all primarily singleauthor dramatists. In the way of theatre business, their plays would get annotated for performance. Some such as The Spanish Tragedy and Dr Faustus would be 
modified by additions or revisions for later revival. But that is another issue from the original commission to write a play. In some cases the trajectory of the dramatist's career shows that single authorship was a preference, an objective they achieved. Jonson famously removed and replaced the work of a collaborator before publishing his Sejanus. Kyd and Marlowe shared a bed-chamber; as far as we know at the moment they did not write together, even though we can only suppose that they wrote in the same room. If we look at a prolific collaborator such as Henry Chettle, whom we have met already, a curious fact emerges. There is a rich and well known source of information in Philip Henslowe's Diary, which gives detailed accounts covering the late 1590s and early 1600s of payments to dramatists by the Admiral's Men and Worcester's Men, major professional theatre companies. If we ask what proportion of Chettle's plays were written in collaboration, we find that a large majority of the works for which Chettle received payments were written in conjunction with other dramatists. But many of these involve writing merely a third of a fifth of a play. If we ask a slightly different question, not 'what proportion of Chettle's plays were written in collaboration' but 'what proportion of Chettle's dramatic writing was commissioned for collaborative plays?'- we can measure this too by the payments Chettle received from Henslowe, and the answer is quite different: something less than half of his writing found its place in collaborations.

I'd also suggest, tentatively, that the situation in the late 1580 s and early 1590s in which Shakespeare emerged was different from the late 1590s, the period covered by Henslowe's Diary, when Jonson, Chapman, Webster, Middleton, Heywood, Dekker, and others emerged. Members of the late 1590s group all learnt their trade by working for the Henslowe companies. Apart from anything else, collaboration worked as a form of training. My impression is that the earlier period depended much more on individual idiosyncrasy--almost a cult of personality, fusing together physical appearance, personal attitude, and literary style, that led to the kind of caricature sketches found in the Groatsworth. These dramatists were university educated, well versed in drama through their reading of Seneca and Plautus, as self-trained professional dramatists self-trained, and in some cases reluctant participants in the theatre trade. In other words, over the course of the decade the theatres, as we might only expect, increasingly institutionalized the training of playwrights.

From this perspective Shakespeare's early collaborations anticipate the theatredriven practices of a decade later. It is in this light easier to understand the affront that Shakespeare presented to the established dramatists. Not a self-proclaimed atheist like Marlowe, not a lifestyle Bohemian like Greene, not in any other respect 
a scandal-monger, Shakespeare, country bumpkin turned ambitious theatre professional, 'supposes he is as well able to bombast out a blanke verse as the best of you'. Well might he be accused of lacking the soul or essence of the true playmaker when he lacked the social and educational substance that was supposed to underpin it.

Those early dramatists were not by temperament collaborators. Greene had collaborated with Lodge of $A$ Looking Glass for England, and according to the Groatsworth, with Nashe on an otherwise unknown play. These two plays are the exceptions; otherwise, with one other exception, the known plays of the university wits were written by sole authorship. That exception is their work in conjunction with the non-professional emergent dramatist Shakespeare. As we have seen, Shakespeare managed to work with Marlowe on the Henry VI plays, with Peele on Titus Andronicus, according to Brian Vickers with Kyd on Edward III, and with one or more further dramatists who remain anonymous on Arden of Faversham and Henry VI. It would come as no surprise if one anonymous turned out to be Greene. At this stage of his career Shakespeare was collaborating more regularly, and we might say more insistently, than anyone else at all. I cannot think of any play before the Henry VI trilogy that was written, as they were, by more than two dramatists. A greater proportion of Shakespeare's early work was collaborative than that of any other dramatist. Proportionally speaking, the early Shakespeare probably on average contributed a lower percentage of lines to the plays in which he was involved than Chettle was to do later. Uniquely, and with repeated success, he broke the preference of Marlowe, Kyd, Peele, and perhaps others to work in isolation. They preferred a mode of writing that was literally academic and studious, metaphorically speaking, monastic. He, Shakespeare, made them participants in collaboration. The Groatsworth seems right in describing Shakespeare's intersection with the established dramatists as appropriative. I add that it was notably promiscuous, and in a way that might strike us as entirely calculated.

How did Shakespeare achieve his special status as promiscuous collaborator? We admire Shakespeare, and it is always tempting to take him away from any scenario in which he might seem to be compromised or contaminated. On this basis we might speculate that Shakespeare's theatre company received completed plays from other dramatists; he, as actor with a rapidly developing literary talent, added some fine flourishes of his own. The implication would be that he did not in the proper sense collaborate with the other dramatists at all; he took what they had finished and supplemented and improved it. It is indeed possible, as I have already suggested, that he revised plays at some time after they were originally staged. But even if this is true, I would have to insist that belated revision cannot fully explain 
his contribution to the texts as we have them. About half of Henry VI parts two and three are in his hand, as is no less than three-quarters of Titus Andronicus. Shakespeare wrote entire scenes and sequences of scenes. He does not merely patch or expand; his writing is absolutely integral to the plays' structure. This is exactly what we would expect of dramatic writing based on a plot, or sketch of the play's action scene-by-scene, as was normal in the early modern theatre, and as would have been particularly necessary in order to plan out a collaborative co-authorship. In other words, attribution studies show Shakespeare working in collaboration in a normal and conventional way. So we have to resist the temptation to see Shakespeare as a dramatist set apart from the other writers, even though he did not belong to them socially or professionally.

I would argue, therefore, that Shakespeare's position as an actor does not set him apart from the other dramatists. More likely, it gives him the capacity to interact with them. After all, it was the theatre company who decided who should write what. It would already be clear that Shakespeare was a capable in-house dramatist. And his ambition to develop his skills could only be to the advantage of the theatre company.

It is useful to think of this development in terms of dramatic genre. In the first instance Shakespeare may have found his own way unaided to writing spritely and elegant comedy by studying Plautus for dramatic construction, and reading prose romances and novellae for plot narrative--though this might not be the whole story, for quite possibly The Taming of the Shrew is a rewrite of a play by Peele. As for the other genres, the particular crafts of composing tragedy and the history play were learnt through collaboration. Tragedy was perhaps the easier of the two technically, because it could be shaped on the established and familiar model of Seneca. Titus Andronicus is strongly modelled on Seneca, collaboratively written with Peele, but with Shakespeare more or less taking over once Peele had supplied the first act. But the English history play was a new genre, and it was forged, above all, through collaborative writing. The full story cannot be told without further investigating questions of both dates of composition and authorship, which cannot be undertaken here, but a provisional summary is presented in the hand-out. The principal players in this history were Marlowe and Shakespeare, and, as Shakespeare moved away from collaboration to sole authorship Marlowe is the one dramatist whose presence haunts his works. It takes another to know oneself alone.

Here, Richard III is the key work, the work in which we can relate the chronology of Shakespeare's career to the content and structure of the play itself. From one angle it looks like Shakespeare's most Marlovian play, with its protracted focus on a single serio-comic tragic protagonist. From another it is Shakespeare's 
declaration of independence: of his mastery of dramatic form and character, even, one might say, his personal ownership of the English historical narrative. It is no accident that the revolutionary break from the Henry VI plays involves a new dramaturgy that focusses on Richard himself. Henry VI offers a chronicle view of history as a chaotic series of events destructively punctuated on the battlefield. In theatre terms, this chronicle view of history corresponds to an ensemble model of the acting company. In 3 Henry VI, for example, the eponymous king is weak, his wife is a more active shaper of events than he is, there is a rival Yorkist king, and the emerging figure Richard Duke of Gloucester has little to contribute until he murders Henry at the end of the play; the play is carried jointly by these various figures, along with lesser but forceful roles such as Richard Duke of York, Clifford, and Clarence. By contrast, no one can remotely compete with Richard Duke of Gloucester's dominance over Richard III. In terms of practical play-making, Richard III celebrates a model that is based not on joint authorship, but on the interdependence of an actor and a playwright. The actor is Richard Burbage, and Shakespeare's expansion and remodelling of the history play depends entirely on his confidence that Burbage can deliver one of the longest and most physically demanding roles he would ever write. This new in-house author-actor dynamic would last twenty years, and is an essential prerequisite for many of Shakespeare's plays, especially the great tragedies. But we might read Richard III not only as a technical assertion of personal and corporate self-sufficiency, but also as a stage representation of singularized authorial selfhood.

Ironically, the lines that most fully represent this idea are from the collaborative 3 Henry VI:

I had no father, I am like no father, <L 5.6.80>

I have no brother, I am like no brother.

And this word 'love', which greybeards call divine,

Be resident in men like one another,

And not in me. I am myself alone.

I believe Shakespeare added these terrifying lines to 3 Henry VI after writing Richard III, as they are not printed in the first edition of 1595. But even if the passage belongs to the original play, it is clear that there are already formal and ideological struggles between the collective principle and the principle of individualism being worked through in the earlier play, with the ideology of single agency being expressed through the figure of Richard himself. And the scenes in which 
Richard plays a prominent role were written by Shakespeare. Hence the Shakespearian parts of the collaborative 3 Henry VI prepare the scene for the emergence not only of Richard as the mainspring of historical action, but also of the triumphantly univocal script that is the play Richard III. One might object, I know, that the sort of arrogant self-separation I am seeing as expressed in Richard is very much in the mould of Marlowe's dramatic heroes. But, to repeat, it takes another to know oneself alone. And Richard's 'I had no father' and 'I have no brother' are not literal truths. They are terrifying for exactly the opposite reason: Richard did have a father, and he does have brothers. His words repudiate the actual fact, subordinating reality to a revolutionary desire. Richard, the principal of reckless will as it imposes itself on an apparently helpless and passive world, the manipulator and seducer, the actor and protean shape-changer: Richard is the emblematic figuration of the actor-and-dramatist (Burbage and Shakespeare), or of the actor-as-dramatist (tautologically, Shakespeare as Shakespeare)_'Richard is Richard: that is, I and I'.

The real point here is not that Shakespeare out-Marlowes Marlowe, nor even that Shakespeare outdoes all the dramatists with whom he has collaborated. The real point is that the Marlovian trope disguises a processing of influence whereby influence is transformed and transcended. Shakespeare understands the Marlovian trope to be arrogance, and he is careful ultimately to distance himself from it. $\mathrm{He}$ understands too that kindness, courtesy, love, kinship, and empathy for suffering, all in short supply in Marlowe, are critical both to humanity and to the kind of drama representing humanity that we call Shakespearian. And it is significant that the line I quoted comes from the point in the play where Richard experiences himself as a fragmented, fearful, and ineffective being. He is disintegrating before our eyes. In this way Shakespeare corrects the Marlovian arrogance he has assumed. It is as though the richly empathetic, diverse, comprehensive Shakespeare we know and celebrate was a product of both the diversity of his collaborative experience and his rejection of it.

After 1592 Shakespeare did not fully collaborate for perhaps fifteen years. There may have been professional play-patching work along the way. Shakespeare's revisions for Sir Thomas More are of this kind. The reasons why he might choose to collaborate with Chettle, Dekker, and Heywood in this task are puzzling and obscure, but one possible answer is that he simply wanted to, or that just very occasionally the collegiality of shared writing was appealing and good for him. Timon of Athens of c. 1607 was almost certainly written with Thomas Middleton; it was Shakespeare's first return to the writing of a collaborative play since the earlier years I have been discussing. If Richard III is a play about a man who has brothers but rhetorically and in one case literally kills them, Timon is a play about a 
man who has no brothers but needs to establish an artificial brotherhood of friends. Timon is indeed both brother and father and even mother to his supposed friends; he is the source of excessive giving that leaves him debt-ridden and full of hate. These themes are interestingly relevant to the play's status as a collaboration. I hope it would not be foolish to suggest that one ingredient in the play's genesis might be a crisis in Shakespeare's sense of himself as a writer. Perhaps he decided to adopt the model of writing as reciprocation in order to recharge his creative batteries. Perhaps, remembering how he learnt his trade in the early 1590s, he needed to return to self-education through shared writing in order to understand the new genre of city comedy. Similar considerations might apply to Pericles, a play about incest and prostitution written soon afterwards in collaboration with the disreputable inn-keeper George Wilkins. In the closing years of his career Shakespeare singled out John Fletcher as a collaborator in several plays. Here, as with his work with Middleton on Timon, Shakespeare was evidently still learning new tricks, in this case bringing the new tragi-comedic mode perfected in Fletcher's Philaster into the storehouse from which he supplied the creativity of his late plays. But Shakespeare was the senior dramatist, and was preparing the way for Fletcher to take over from him as the regular playwright of the King's Men. Shakespeare and Fletcher were reciprocally teacher and apprentice to each other, just as Shakespeare himself had earlier been both learner and over-reacher.

At the beginning of this paper I quoted the epigram to Venus and Adonis and related it to Shakespeare's rejection of collaborative writing. The argument is based partly on chronology: there is a stage in Shakespeare's career where he turns away from collaboration, displays his skills as a non-dramatic poet, and soon after sets up as shareholding member of the Lord Chamberlain's Men. In this way the boundary dispute of 1592 was settled by Shakespeare's self-insulation from other dramatists and the theatre company's self-sufficiency through its internalization of dramatic writing. These are the developments that give us Shakespeare the accomplished writer in the institutional setting that would sustain him for two decades. If that stable set-up was itself commercial, it nevertheless enabled Shakespeare to exercise what was-otherwise-relative autonomy.

But his is not the same thing as drinking at the uncontaminated Castalian springs, and indeed when Shakespeare wrote Venus and Adonis he had not yet even achieved the position of theatre company shareholder. That is why I read the epigram not as a rejection of theatre entirely—that could scarcely be-but as a rejection of collaboration as a practice that up to this point he had embraced to excess. His eagerness to collaborate in the years up to and including 1592 strikes me as unusual among the dramatists of that moment. His promiscuous collabora- 
tion may have been driven by creative energy and desire to share with the established and great dramatists in the mystery of their profession. It may have been a calculated attempt to exploit collaboration in order to move on and exploit the skills learnt through shared writing by writing on his own. We cannot know. But my argument, which is essentially about the emergence of genius, amounts to two statements. First the material circumstances that we can describe with increasing clarity draw a picture of a Shakespeare who shared in order to become separate; his acts of collaboration enable his acts of sole authorship and are, I would suggest, entirely necessary. From this point of view his arrogant boast about drinking from the Castalian springs is unsustainable as a model for his dramatic writing. The source of that writing is not mythical; it does not flow purely from the act of a rapacious god turning a fleeing woman into stone. Shakespearian drama is always shot through with the Mercurial as well as the Apollonian. Second, the material circumstances are nevertheless insufficient as an explanation of Shakespeare's sole-authored plays. The synthesis is not merely a synthesis of precedents. It is a synthesis between the sum of precedents and the creative act of writing, an act that Shakespeare would surely have understood as metamorphosis.

\section{Bibliography}

Hugh Craig, "The Three Parts of Henry VI", Shakespeare, Computers and the Mystery of Authorship. , Eds. Craig and Kinney. Cambridge: Cambridge University Press, 2009. 40-77. 